\title{
Mangrove Plantation as a Tourist Attraction in San Juan Batangas, Philippines
}

\author{
Sarah Jane M. Miranda, Joy O. Reyes, Anne Tan, Letlet C. Villanueva, \\ Sarah Mae F. Zara, Amada G. Banaag, Renato Rosales \\ College of International Tourism and Hospitality Management, \\ Lyceum of the Philippines University, Batangas City, \\ Philippines
}

DOI: $\quad 10.6007 /$ IJARBSS/v3-i8/158 URL: http://dx.doi.org/10.6007/IJARBSS/v3-i8/158

\begin{abstract}
This study about the Mangrove Plantation in San Juan, Batangas, Philippines aimed to identify the potential of mangrove plantation as a tourist attraction; to describe the status of mangroves, the programs offered by the government; to determine the level of support given by the government; to determine the benefits of the mangroves; and to propose an action plan that will develop the mangrove plantation as a tourist attraction. The study used descriptive method in order to determine the needed information regarding the current status of mangrove plantation as tourist attraction. The study concluded that the status of the mangroves in the coastal areas of San Juan, Batangas is continuously propagating and the local government does not neglect the mangrove plantations in the said community, as such, it is properly protected; the government's level of support given to the mangrove plantation in terms of policies, management and planning and budget are highly implemented while in terms of promotion is implemented only; mangroves are beneficial to the residents of San Juan particularly in terms of environmental/ecological, economic and health, and ; proposed an action plan regarding development of Mangrove Plantation was designed by the researchers.
\end{abstract}

Keywords: Mangrove, Plantation, Tourist Attraction, Tourism, San Juan Batangas, Philippines

\section{INTRODUCTION}

Responsible tourism is about providing better holiday experiences for guests and good business opportunities to enjoy better quality of life through increased socio-economic benefits and improved natural resource management (Ashley et. al., 2008). The mangrove also helps in the preservation of the soil, thus preventing soil erosion. According to Pulhin and Pampolina, (2008) " mangrove species are able to reduce the amount of excess carbon in the air, thus lessen the greenhouse gas' contribution to global warming by sequestering atmospheric carbon dioxide, a greenhouse gas contributes as much as $26 \%$ to the greenhouse effect. Every policy should be a 
long range master plan and should be purposed to distribute the benefits of tourism (Karma, 2005).

Due to the demands of the increasing population of the human world, certain methods were created in order for the human world to better adapt to its surroundings and at the same time, co-exist with the natural world. In relation to this, certain problems like the depletion of the ozone layer caused by the emission of green house gases like Carbon Monoxide, Chlorofluorocarbons or CFC's, Sulphur, Carbon Dioxide and any other harmful chemicals or components are now a major concern in the contemporary world.

In this case, the researchers have found out an idea on how to lessen this problem and this is the continuous planting and preservation of the Rhizophora species or commonly known as mangrove in the vicinity of San Juan, Batangas. Furthermore the study is conducted because the researchers observed that there is a need and is a responsibility for us that the natural environment especially the mangrove ecosystem, be taken cared of, to be protected, preserved and properly managed, for it could be a way of restoring balance in nature and also it can be a means of livelihood for the locals, through responsible ecotourism. Another is to restore and improve connection with nature itself.

\section{OBJECTIVES OF THE STUDY}

This study aimed to promote the mangrove plantation in San Juan, Batangas as a tourist attraction. More specifically, it described the status of mangrove plantation in terms of its area, species, condition and life span. This also determined the programs offered by the government to develop mangrove plantation as a tourist attraction. Also, it determined the government's level of support given to the mangrove plantation in terms of policies, management and planning, budget and promotion and benefits of the mangrove plantation in terms of ecological / environmental, economic and health. Finally, it proposed an action plan that will develop the mangrove plantation as a tourist attraction.

For economic aspect, Mangrove plantation provides livelihood for the local people, through ecotourism sites, like the Banacon Island Mangrove Forest and Candijay Mangrove Forest in Bohol, Mangrove Eco-Tourism Park "Katunggan It Ibajay in Aklan, and Triboa Bay MangroveP ark in Subic Bay. Mangrove areas are also sources of wild fry and juvenile fish for the aquaculture industry. In addition, mangrove seeds and saplings can be harvested and sold to reforest denuded areas. However, for health aspect,it can be used as medicine to reduce blood pressure, asthma, fever, convulsion, and sore throat. It can even treat leprosy and rheumatic disorders. The bark of Rhizophora species possess astringent qualities and some species are capable of treating diarrhea when extracted from leaves and prepared as beverage.

In an article "Carbon Stock Assessment of a Mangrove System in San Juan, Batangas" published in the Journal of Environmental Science and Management (JESAM) in June 2008, the UPLB researchers mentioned two mangrove systems in San Juan, Batangas: in Barangays Poctol, Pinagbayanan and Catmon, where 100 hectares are planted to mangroves. In these sites, the 
Bakawan (Rhizophora sp.), Tabigi (Xylocarpusgranatum), and Bungalon (Avicennia marina) are dominant mangrove species planted.

\section{MATERIALS AND METHOD}

Descriptive method was utilized employing both qualitative and quantitative approaches. Descriptive research design was used in the study. The informants are composed of three Government employees to whom the positions are municipal administrator of San Juan, Batangas, the head Municipal Agriculturist of San Juan Batangas, and the Chief BantayDagat which is also a representative of the (Community Environment and Natural Resources Office) CENRO. The researchers used Quota sampling in order to determine the number of respondents. The respondents of the study were 15 government officials who are concerned with the Mangrove Plantation and 30 respondents that will determine the benefits of the mangroves. Quota sampling is a type of judgment sampling which quotas are set according to some characteristics of the population.

The researchers immediately conducted an interview with the head Municipal Agriculturist of San Juan Batangas, and the Chief Bantay Dagat which is also a representative of the (Community Environment and Natural Resources Office) CENRO to support the different data for the questionnaire. After the interview, the researchers constructed a self-made questionnaire based on the results of the interview and with the aid of existing studies involving Mangroves. The data were gathered through interview with the survey questionnaires consisted of two parts.

Part I includes the assessment of the level of support of the government on Mangrove Plantation in terms of policies, management and planning, budget and promotion. Part II consists of the environmental, economic and health benefit that the Mangroves produced.

The researchers formulated the research title and presented it to the adviser for suggestions, revisions and approval. After the approval of the title, the researchers started to research for information using various resources like face to face interview, books, journals, internet, and magazines, published and unpublished thesis. Next to it was the construction of self-made questionnaires to be used as guide for the research. The draft went to various revisions and was validated with the help of professors and tourism instructors. Ranking and weighted mean were also used as statistical tools to interpret the gathered data.

\section{RESULTS AND DISCUSSION}

There are many species of mangroves such as Bakawan, a tagalog name of the mangrove, pipisiknaitim/puti, a specie, characterized by black or white inflorescence or cluster of flowers, Buta (nakakalason) or poisonous due to its milky sap which contains cyanide properties, Pagatpat (nabungangbilog), Nigi (ginagawang puzzle), Aroma(may tinik) has thorns, Dungon( strives in swampy areas), Libato (napakatigas na kahoy) characterized by having a hard 
structure. According to the interviewees, most mangrove species lasts twenty years to hundreds of years of life span. The mangrove species have a lot of varying names all over the world and is fully known by its Latin name or scientific name authored by the father of taxonomy Carolus Linnaeus.

The word "Mangroves" refers to a group of plants which may actually belong to several families (species that distinctly belong to their own evolutionary group). The term therefore indicates an ecological rather than a taxonomical (scientific classification) grouping - the species are not related. They are unique plants because of their ability to grow in unstable tough environments.

Mangroves are unique because they are able to thrive in areas where the water is poor in oxygen content, in salt water, in fresh water and in brackish water (a mixture of salt and fresh water). Mangroves are fast-growing trees taking several years to reach up to 25 meters when they are fully grown. Of the seven types of mangroves, three are most dominant; the red, black and white types.

There are other plantation of mangroves aside from Barangay Pinagbayanan, Poctol and Catmon. These areas are the following: Imelda, Balwarte, Subukin, Nagsaulay, Calubcub, Tikalan, Bataan, and Laiya. Among these places, Imelda has the most grown and has the most number of mangroves.

The Philippines is a tropical country. It is characterized as humid and has a dense climate which is appropriate for plant to grow like mangrove species which can propagate and able to grew and live for long period of time. In relation to coastal or intertidal areas of San Juan, Batangas, its rich and soft soil is suitable for the needs of the mangrove species.

The most used activity on how the local government collaborate with the residents and any existing parties like the Conservation International. The information education campaign is a kind of awareness seminar given to the residents and to the tourists who are about to undergo mangrove tree planting or any similar activities, it is also an activity wherein the nongovernment, residents and government representatives collaborate in demonstrating information education communication focused on coastal management.

In Banacon, Bohol as the local government collaborates with the local residents by encouraging them to join walk for a cause, fun run, in behalf of creating funds in developing mangroves preservation areas, also in "plant a mangrove" activities. Certain incentives are given to those who are joining in the said activities. Even though it is highly banned to cut mangroves, there are some who sell parts and its sapling without proper coordination with the government particularly in Aklan and in Bulacan, The local government would conduct livelihood programs on the other uses of mangroves such as the saplings to be propagated and to be sold in other needy coastal areas. The promotion of aquasilviculture or the proper cultivation and selling of shrimps, milkfish, lobsters and other crustaceans may improve the quality of life in the area.

\section{Mean score of the government support in the Mangrove Plantation}


The respondents believed that government supports are implemented in the Mangrove Plantation with a weighted mean of 3.4919. Results also shows that the policies which include Municipal ordinance (2006) on Comprehensive Coastal Resource Management (WM=3.8667) and R.A. 8550 (protection of coastal areas) are highly implemented. This implies that most of the residents and the neighboring barangays of the Barangay Pinagbayanan are aware of the policies and understands the consequences of the action.

The respondents believed that government support to management and planning is highly implemented with a composite mean of 3.8889. It can be seen from the table that the highest among the government support in terms of management and planning is the employment of the Bantay-Dagat with a weighted mean of 3.9556 and a verbal interpretation of "highly implemented". Conservation and protection program for the coastal areas of San Juan (WM=3.8667), consistent collaboration with DENR and CENRO (WM=3.8667) and government raised Coastal Clean-up to maintain the cleanliness in the mangrove areas are of the same rank with a verbal interpretation of "highly implemented".

This implies that the government is visible in terms of preserving the Mangrove plantation/preservation. In addition, the results also show that the residents are cooperative in collaborating with the government and that they do it not because of being a part of community service but as part of their culture to preserve and to help create planting programs.

The respondents believed that government support to budget is highly implemented with a composite mean of 3.61. It can be seen from the table that the highest among the government support in terms of budget is the government hired caretakers for the mangrove plantation with a weighted mean of 3.8667 and a verbal interpretation of "highly implemented". The government provide saplings, and any equipment needed for the residents to propagate the mangroves (WM=3.47), and the government raised income generating project for the Mangrove Plantation (WM $=3.49)$ are of the same verbal interpretation of "implemented". This implies that the government still cares and pays attention for the well-being of the natural environment, focusing on the coastal areas, where mangrove species are abundant.

The government support to promotion is implemented with a composite mean of 2.60. It can be seen from the table that the highest among the government support in terms of promotion is word of mouth with a weighted mean of 3.5556 and a verbal interpretation of "highly implemented". Collaboration with private entities (WM=3.02) has a verbal interpretation of "implemented". Flyers/brochures/ magazines (WM=2.11), TV/radio commercials (WM=2.33), and official website's $(\mathrm{WM}=2.00)$ are of the same verbal interpretation of "moderately implemented". This implies that the mangrove and any activities connected to it like coastal management seminars and mangrove sapling propagation are highly known by word of mouth which is cheapest yet effective form of communication/promotion.

Mangrove proves to be highly beneficial in terms of ecology. The local residents could also appreciate more of the existence of the mangroves if the local government would conduct in 
depth seminars on coastal management, focusing on mangroves. And provide incentives to those who would create innovative ideas on proper management.

In terms of economic benefits, the Mangrove Plantation is beneficial with a composite mean of 3.24. The respondents believed that Mangrove Plantation is highly beneficial for it provides a source of income thru continuous planting/ propagation ( $W M=3.62)$. Provides livelihood through tourism (WM=3.38) and Provides food and other primary resources $(W M=2.71)$ having the same verbal interpretation of "beneficial".

This shows that mangroves worth its existence. In addition, the mangrove rehabilitation area in Subic, Zambales, Banacon, Bohol and also in Aklan, wherein the economies in the said areas mainly depend on ecotourism upgraded the status of life of the residents.

In terms of health benefits, the Mangrove Plantation is moderately beneficial with a composite mean of 1.77. The respondents believed that Mangrove Plantation is moderately beneficial in providing medicine $(W M=1.91)$, the bark, roots and fruits make good mosquito repellants (WM=1.64), and it can cure asthma, fever, convulsion and sore throat ( $W M=1.76)$.

This illustrates that some residents do not know the health benefits of the mangrove, in relation to the said policies of prohibiting the cutting of mangroves while most of the respondents gained their knowledge on the mangroves and its benefits through free seminars or as part of their jobs. Moreover, there are several other health benefits of mangroves where in Banacon, Bohol, the locals use the extracts from the mangrove leaves, roots and barks as a medicine for diarrhea. And the roots of some species like the Derris Trifoliata are used as a cure for rheumatic disorders.

\section{CONCLUSION AND RECOMMENDATION}

The status of the mangroves in the coastal areas of San Juan, Batangas is continuously propagating and the local government does not neglect the mangrove plantations in the said Barangays, thus it is properly protected. The government's level of support given to the mangrove plantation in terms of policies, management and planning and budget are highly implemented while in terms of promotion is implemented only. Mangroves are beneficial to the residents of San Juan particularly in terms of environmental/ecological, economic and health. Proposed action plan regarding development of Mangrove Plantation was designed by the researchers.

Local government and local tourism may provide marketing strategy for promoting mangrove plantation as a tourist attraction in the community. Consistent and proper communication with the Barangay officials and the Mangrove itself and its benefits may be incorporated in the education starting with the primary education. Seminars maybe conducted and translated into a more friendly language. Government may use the action plan that was proposed by the 
researchers for the development of Mangrove Plantation. A replication of this study in other locale or variable is suggested.

\section{REFERENCES}

Ashley, et. al. And edited by Spenceley, A. (2008). Responsible tourism: Critical issues for conservation and development. Earthscan 2 park square, Milton park, Abingdon, Oxfordshire, UK.

Karma, K. (2005). Managing tourist destination. Kanishka Publishers, Distributors, Ansari Road, Daryaganj, New Delhi.

Pulhin, F.B. \& Pampolina, N.M. (2008).Carbon stock assessment of a mangroveecosytem in san juanbatangas. Journal of Environmental Science and Management, Vol. 11, No. 1 (2008) 